J. Clin. Chem. Clin. Biochem.

Vol. 24, 1986, pp. $641-646$

(C) 1986 Walter de Gruyter \& Co.

Berlin - New York

\title{
Clinical Relevance of Alkaline Phosphatase Isoenzyme Determinations by High Performance Liquid Chromatography
}

\author{
By E. Schönau, K. H. Herzog and H.-J. Böhles
}

Kinderklinik und Poliklinik (Direktor: Prof. Dr. Stehr) der Friedrich-Alexander Universität Erlangen-Nürnberg

(Received November 14, 1985/February 17, 1986)

Summary: A new method for the separation of alkaline phosphatase isoenzymes by means of high performance liquid chromatography (HPLC) is presented. One isoenzyme was identified in homogenate of small intestine, two were identified in bone, and two in liver, and fragment and biliary isoenzymes were identified in bile. Sera from 32 patients with different diseases of the skeletal system or the liver were analysed. High activities of the bone isoenzymes were detected in bone diseases, of the second liver isoenzyme in acute hepatitis and of the first liver and biliary isoenzymes in biliary obstruction. There are indications that the first liver isoenzyme is derived from the cell membrane and the second liver isoenzyme from the cytosol. The biliary isoenzyme is considered to be a highly sensitive and specific indicator for cholestasis.

\section{Klinische Bedeutung der Isoenzyme der alkalischen Phosphatase bei Bestimmung durch Hochleistungsflüssig- keitschromatographie}

Zusammenfassung: Beschrieben wird eine neue Methode der Trennung der Isoenzyme der alkalischen Phosphatase durch Anwendung der Hochleistungsflüssigkeitschromatographie (HPLC). In Gewebehomogenaten wurden ein Dünndarm-, zwei Knochen-, zwei Leber-, Abbau- und biliäre Isoenzyme nachgewiesen. Untersucht wurden 32 Patientenseren mit verschiedenen ossären und hepatischen Erkrankungen. Nachgewiesen wurden erhöhte Aktivitäten der Knochenisoenzyme bei rachitischen Prozessen, des zweiten Leberisoenzyms bei akuten Hepatitiden und des ersten Leberisoenzyms sowie biliären Isoenzyms unter Cholestase. Es gibt Hinweise, daß das erste Leberisoenzym der membranständigen und das zweite Leberisoenzym der zytosolischen Form der Leberphosphatase entspricht. Diskutiert wird das biliäre Isoenzym als sehr empfindlicher und spezifischer Indikator für Cholesțasen.

\section{Introduction}

Alkaline phosphatase (EC 3.1.3.1) is a dimeric zinccontaining glycoprotein. It is involved in the transport of fatty acids, calcium and phosphate across the membranes of small intestine (1). Its function in the liver still has to be clarified. Under physiological circumstances human serum contains isoenzymes derived from liver; bone and small intestine, and in pregnancy from the placenta as well. Placental alkaline phosphatase becomes detectable in serum between the 16th and 20th week of gestation (2). Isoenzymes considered as pathological are the biliary iso- enzyme, which appears in biliary obstruction, and the Regan isoenzyme, which can be detected in 3 to $15 \%$ of patients with cancer (3). The heterogeneity of the isoenzymes is partly due to genetic factors and partly to posttranslational modifications. Mc Kenna et al. demonstrated the primary structural identity of the liver, bone and renal isoenzymes and the dissimilarity of the placental and intestinal forms (4). Posttranslational glycosylation causes variations in $\mathrm{pI}$ and is responsible for the differences between liver and bone isoenzymes. The $\mathrm{pI}$ of liver isoenzyme is slightly more acidic than that of bone. The intestinal isoenzyme is 
the most basic and the biliary the most acidic of all the known forms $(5,6)$. Hitherto, the alkaline phosphatase isoenzymes have been measured by means of chemical inhibitors (7-11), heat inactivation (12) and different electrophoretical methods (13-15). Using immunological methods it is possible to differentiate between the isoenzyme groups of bone, liver, kidney and intestine or placenta $(16,17)$. Nevertheless none of these methods is satisfactory for a precise differentiation of the bone from the liver isoenzyme, which represents the main diagnostic problem when alkaline phosphatase activities are pathologically elevated.

In the usual electrophoretic separations, the bone and liver isoenzymes overlap, owing to their similar pI's. These separations allow only a visual assesment of the relative proportions of isoenzymes. Also the heat inactivation and the chemical inhibition methods only permit semiquantitative estimations. We describe a quick and reproducible method for a clear separation of alkaline phosphatase isoenzymes by means of high performance liquid chromatography (HPLC).

\section{Materials and Methods}

\section{Materials}

For the HPLC-separation, a Gilson Model 302 pump (Abimed, Düsseldorf, FRG) was used. The gradient was formed by a 11300 ultrograd gradient mixer (LKB, Bromma, Sweden). For the chromatographic separations, Pharmacia prepacked Mono Q HR 5/5 (5 mm $\times 50 \mathrm{~mm})$ columns (Uppsala, Sweden) were used; these consist of a strong anion exchanger, the charged group on the gel being $-\mathrm{CH}_{2}-\mathrm{N}\left(\mathrm{CH}_{3}\right)_{3}^{+}$. Diethanolamine was obtained from Fluka (Buchs, Switzerland); Tris, $\mathrm{HCl}, \mathrm{LiCl}, 4$ nitrophenyl phosphate and $L$-phenylalanine, p. a. grade, from E. Merck (Darmstadt, FRG).

\section{Methods}

The Mono $Q$ HR 5/5-column was equilibrated with $10 \mathrm{ml}$ $1 \mathrm{~mol} / 1$ Tris $\mathrm{HCl}$ buffer $\mathrm{pH} 8.2$ and $5 \mathrm{ml} 20 \mathrm{mmol} / 1$ Tris $\mathrm{HCl}$ buffer $\mathrm{pH} 8.2$ at a flow rate of $1 \mathrm{ml} / \mathrm{min}$. Sera were centrifuged for five minutes at $8000 \mathrm{~g}$. Between one hundred and four hundred microlitres of serum were: diluted to $1 \mathrm{ml}$ with 20 mmol/1 Tris $\mathrm{HCl}$. The most precise separations were obtained with a sample volume of $100 \mu$ l. After application of the sample to the column, the isoenzymes were eluted stepwise with an $\mathrm{LiCl}$-gradient (see fig. 1) at a flow rate of $1 \mathrm{ml} / \mathrm{min}$. Fractions of 10 drops each were collected. After elution, remnants of protein were removed from the column with $1 \mathrm{ml}$ of $1 \mathrm{~mol} / 1$ $\mathrm{NaCl}$. The enzyme activity was constantly measured in 100 fractions. A substrate concentration of $5 \mathrm{mmol} / 1$ 4-nitrophenylphosphate in $0.5 \mathrm{~mol} / 1$ diethanolamine hydrochloride $\mathrm{pH} 9.8$ and in the presence of $0.5 \mathrm{mmol} / \mathrm{l} \mathrm{MgCl}_{2}$ gave a zero order reaction of isoenzyme activity at $25^{\circ} \mathrm{C}$ during the measurement period of two minutes.

Homogenates of liver, small intestine and vertebral spongiosa were used for the identification of isoenzymes. Tissues obtained within 24 hours post mortem from adult patients were homogenized in $20 \mathrm{mmol} / \mathrm{l} \mathrm{Tris} / \mathrm{HCl}$ buffer $\mathrm{pH} 8.2$, then frozen and thawed three times. After centrifugation for 15 minutes at $8000 \mathrm{~g}$ interfering lipids were removed with Freon. Bile drained from postcholecystectomy patients was collected and used for the identification of the biliary isoenzyme. The serum from patients with transient hyperphosphatasaemia was heated for 15 minutes at $56^{\circ} \mathrm{C}$ to demonstrate the different heat stabilities of the separated isoenzymes. Isolated isoenzyme fractions were treated with $5 \mathrm{mmol} / \mathrm{l} L$-phenylalanine.

\section{Results}

The sequence of the eluted alkaline phosphatase isoenzymes is shown in figure 2. Standard deviation of the peak maximum is $s= \pm 2$ fractions. The isoenzyme of small intestine was eluted first at a $\mathrm{LiCl}$ concentration of $90 \mathrm{mmol} / \mathrm{l}$. In some separations this isoenzyme overlapped with the first of the bone isozymes. This overlap is demonstrated in the serum eluate of a patient with osteomyelitis. Thereafter the

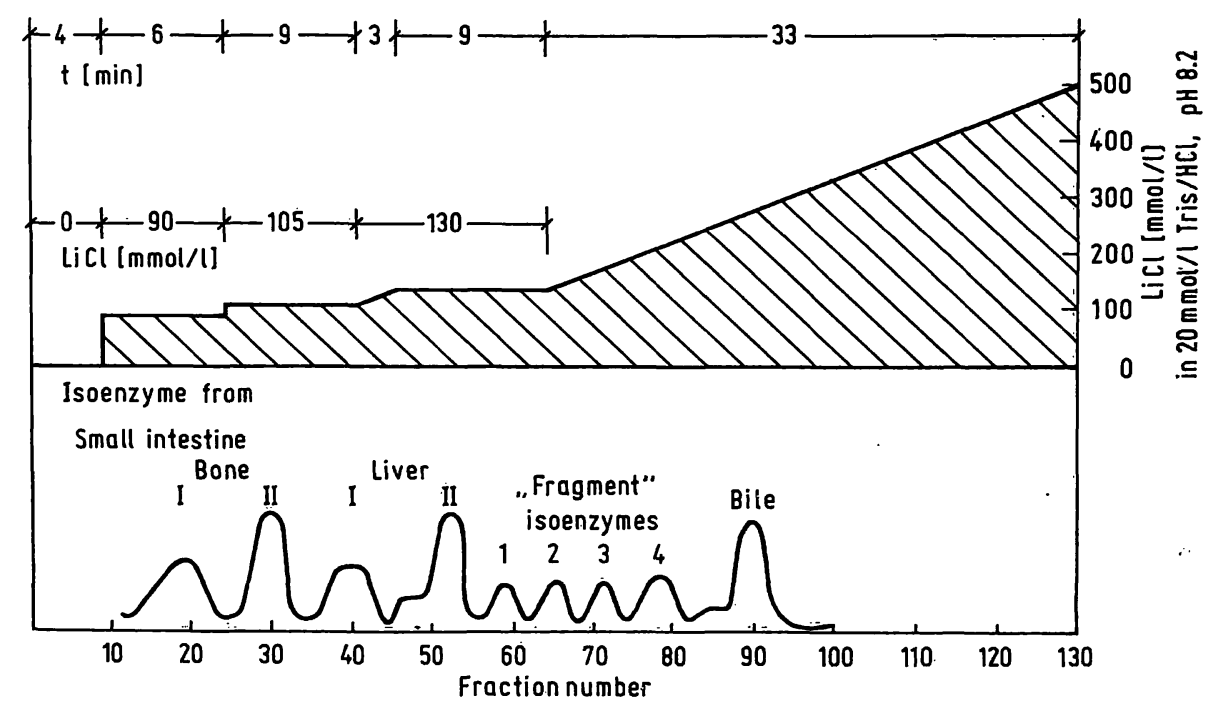

Fig. 1. Schematic compilation of methodology used. From top to bottom are the elution time of each $\mathrm{LiCl}$ concentration, the steps of $\mathrm{LiCl}$ concentrations and the respectively fraction numbers. For illustration a fictional elution pattern is used. 


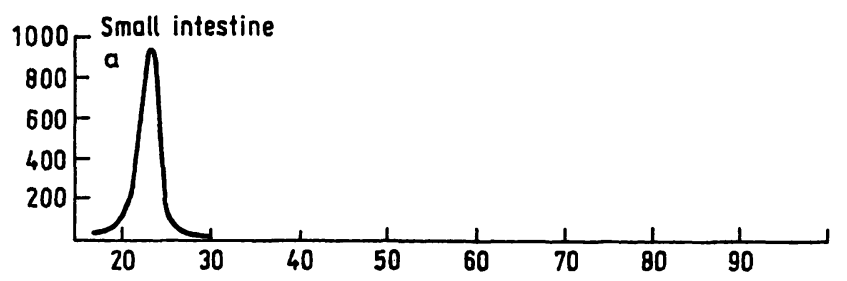

\section{Case Reports}

Sera from 32 patients with several types of hepatitis $(n=8)$, cholestasis $(n=6)$, liver cirrhosis $(n=6)$, several bone tumours $(n=5)$, phosphate diabetes $(n=1)$, rickets $(n=1)$, osteomyelitis $(n=2)$ and transient hyperphosphatasaemia $(n=3)$ were exam-

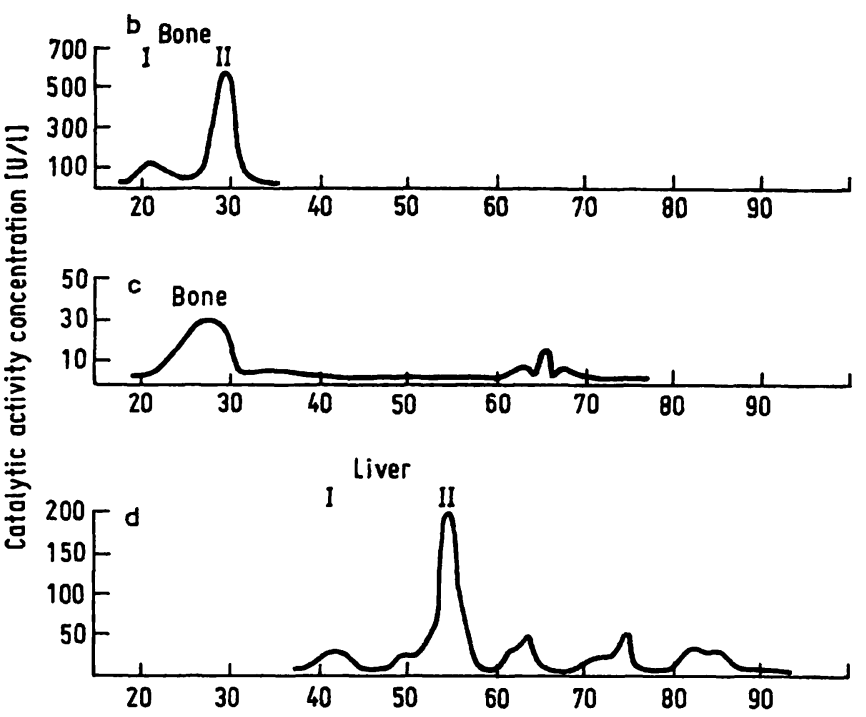
ined and compared with healthy controls $(n=15)$.

Different isoenzyme patterns were found at different stages of development (fig. 3). For instance, the isoenzyme pattern of a new-born child is characterized by high activities of the liver isoenzymes. During infancy the bone isoenzymes become predominant. After the growth period of infancy the isoenzymes of liver remain, while the activities of the bone forms decrease.

The distribution of the isoenzyme activities in bone diseases is presented in figure 4. Separation 9 from a male infant with phosphate diabetes shows an increased activity of the bone isoenzyme. Separations 10 and 11 show isoenzyme activities in a case of osteosarcoma before and after 50 days therapy with

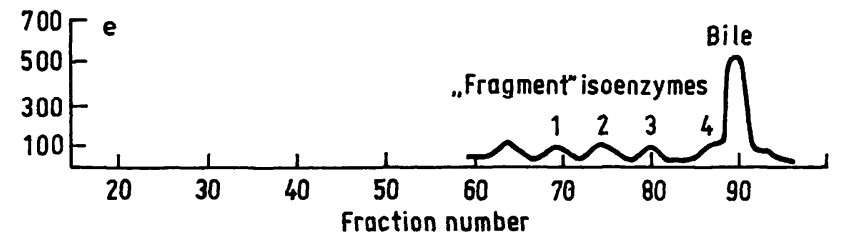

Fig. 2. Isoenzyme pattern of tissue extracts and serum of osteomyelitis patient.

\begin{tabular}{lrl}
\hline \multicolumn{1}{c}{ Sample } & $\begin{array}{l}\text { Total } \\
\text { activity }\end{array}$ & $\begin{array}{l}\text { Volume } \\
(\mathrm{U} / \mathrm{l})\end{array}$ \\
& $(\mu \mathrm{l})$ \\
\hline a) small intestine homogenate & 1200 & 100 \\
b) serum & 287 & 400 \\
c) vertebral spongiosa homogenate & 30 & 500 \\
d) liver homogenate & 1200 & 200 \\
e) bile fluid & 1000 & 300 \\
\hline
\end{tabular}

second isoenzyme of bone was eluted by $105 \mathrm{mmol} / 1$ $\mathrm{LiCl}$. In sera we could generally identify two liver isoenzymes. In liver extracts, however, only a small activity of the first liver isoenzyme, eluted by 105 $\mathrm{mmol} / 1 \mathrm{LiCl}$, was detected. The second liver isoenzyme was eluted by $130 \mathrm{mmol} / \mathrm{l} \mathrm{LiCl}$. The main bile fraction followed at $\mathrm{LiCl}$ concentrations between $185-230 \mathrm{mmol} / \mathrm{l}$. In addition, up to four isoenzyme peaks were counted between the second liver isoenzyme and the biliary isoenzyme; we named these fragment isoenzymes. By heat inactivation, $95 \%$ of bone and $75 \%$ of liver isoenzyme activity were inactivated. Under treatment with $5 \mathrm{mmol} / \mathrm{l} L$-phenylalanine, $80 \%$ of small intestine, $13 \%$ and $12 \%$ of bone, and $14 \%$ and $16 \%$ of liver isoenzyme activity were inhibited. platinex, adriamycin and methotrexate. As a result of the cytostatic therapy, the activities of bone isoenzymes were reduced.

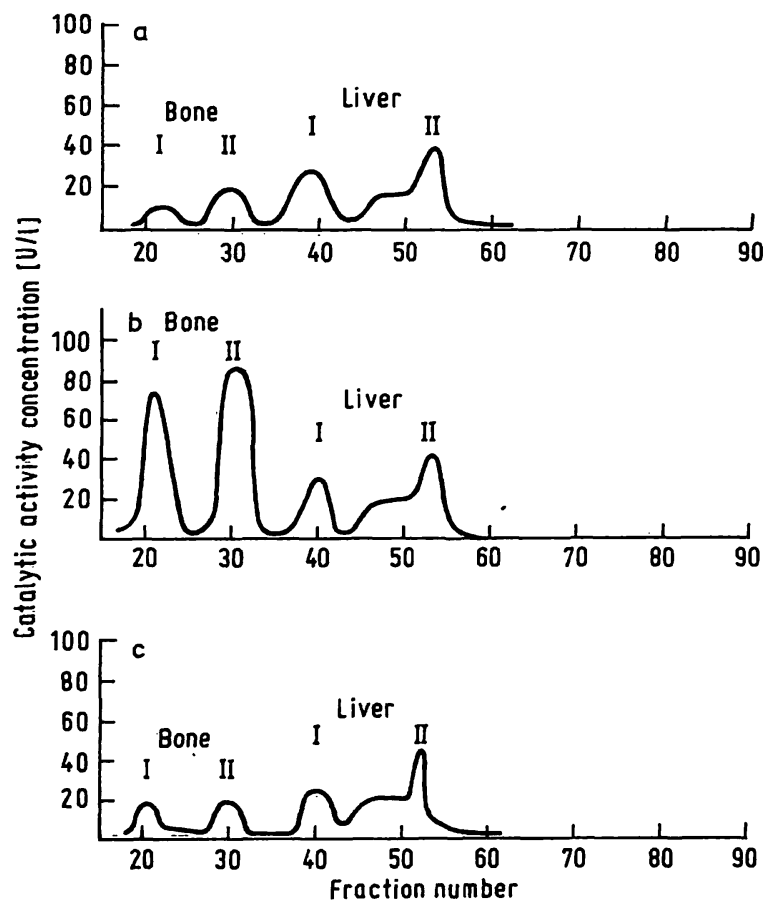

Fig. 3. Serum isoenzyme pattern of normal controls of different age groups.

\begin{tabular}{lll}
\hline Sample & $\begin{array}{l}\text { Total } \\
\text { activity } \\
(\mathrm{U} / \mathrm{l})\end{array}$ & $\begin{array}{l}\text { Volume } \\
(\mu \mathrm{l})\end{array}$ \\
\hline & 189 & 100 \\
\hline a) serum, ơ, 1 day old & 553 & 100 \\
b) serum, ơ, 11 years old & 155 & 100 \\
c) serum, $\$, 56$ years old & & \\
\hline
\end{tabular}




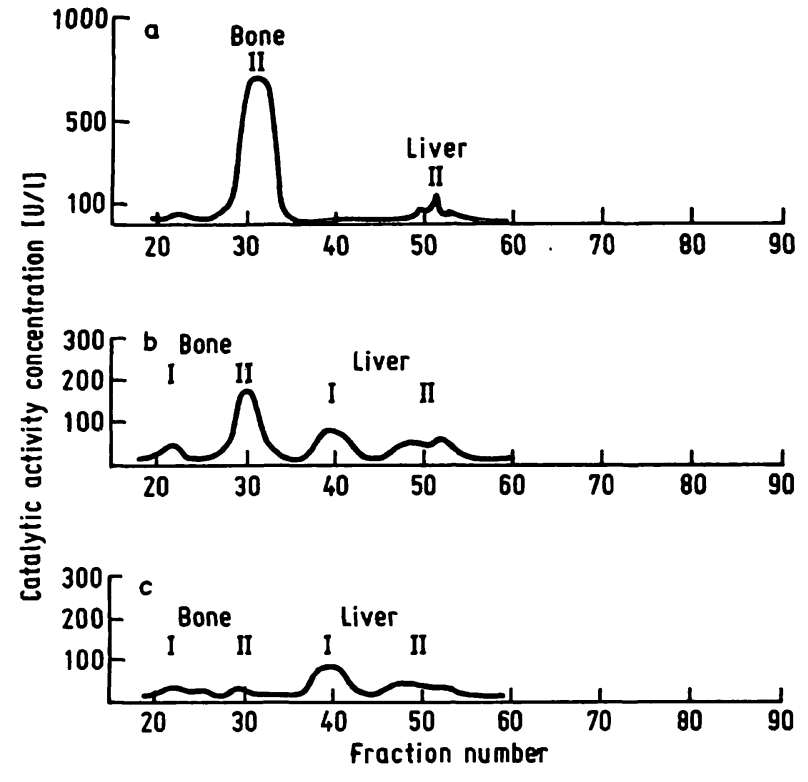

Fig. 4. Serum isoenzyme pattern in cases of bone diseases.

\begin{tabular}{lll}
\hline Sample & $\begin{array}{l}\text { Total } \\
\text { activity } \\
(\mathrm{U} / \mathrm{l})\end{array}$ & $\begin{array}{l}\text { Volume } \\
(\mu \mathrm{l})\end{array}$ \\
\hline $\begin{array}{l}\text { a) serum }(\delta, 1 \mathrm{a}) \text { phosphate } \\
\text { diabetes }\end{array}$ & 788 & 200 \\
$\begin{array}{l}\text { b) serum }(\delta, 14 \text { a) osteosarcoma } \\
\text { before therapy }\end{array}$ & 170 & 300 \\
$\begin{array}{l}\text { as b), after 50 days cytostatic } \\
\text { therapy }\end{array}$ & 95 & 300 \\
\hline
\end{tabular}

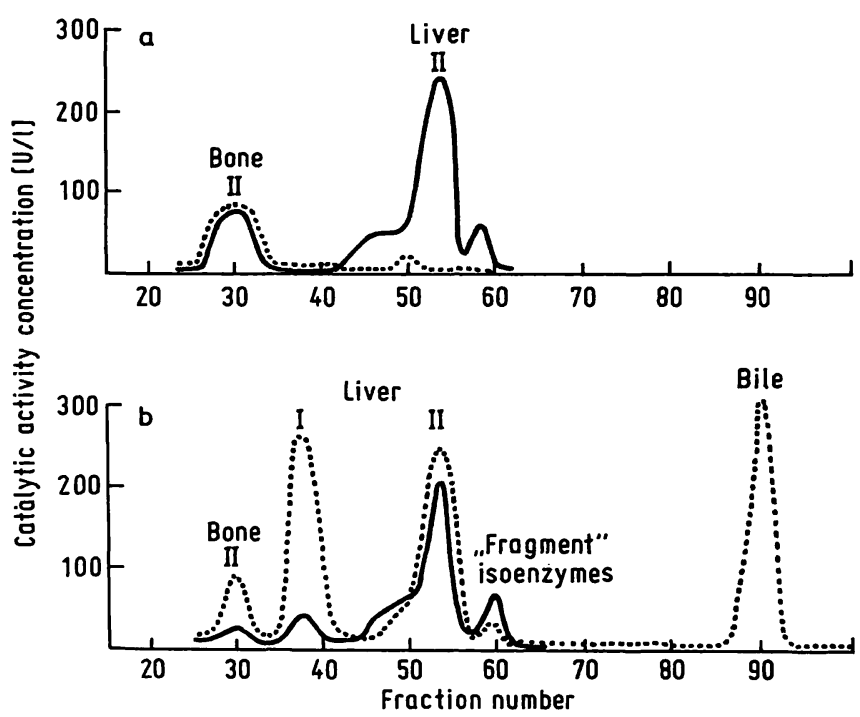

Fig. 5. Serum isoenzyme pattern in cases of hepatobiliary diseases.

\begin{tabular}{|c|c|c|}
\hline Sample & $\begin{array}{l}\text { Total } \\
\text { activity } \\
(\mathrm{U} / \mathrm{l})\end{array}$ & $\begin{array}{l}\text { Volume } \\
\text { ( } \mu \mathrm{l})\end{array}$ \\
\hline $\begin{array}{l}\text { a) hepatitis }(\delta, 12 \text { a) } \\
\text { serum, acute stage }(-)\end{array}$ & 1300 & 100 \\
\hline $\begin{array}{l}\text { after therapy }(\ldots) \\
\text { b) liver }(\delta, 20 \text { a) infiltrated by } \\
\text { hydratid cysts }\end{array}$ & 280 & 100 \\
\hline $\begin{array}{r}\text { serum, before cholestasis }(-) \\
\text { during cholestasis }(\ldots)\end{array}$ & $\begin{array}{r}780 \\
2200\end{array}$ & $\begin{array}{l}100 \\
100\end{array}$ \\
\hline
\end{tabular}

Figure 5 shows the isoenzyme activities in cases of hepatitis and cholestasis. In all examined cases of hepatitis it was demonstrated that the second liver isoenzyme represents the major part of the total alkaline phosphatase activity. Separation 13 shows the appearance of the biliary isoenzyme during cholestasis. In this case the isoenzyme activities from a 20 year-old male patient are shown, whose liver was infiltrated by hydatid cysts. The same patient developed cholestasis as a consequence of acute pancreatitis. The rise of the total alkaline phosphatase activity was mainly produced by the increase of the first liver isoenzyme and the appearance of the biliary isoenzyme.

Figure 6 presents the development of isoenzyme activities in a 9 week-old male infant, who had hepatitis $B$ and subsequently developed rickets. Separation 14 describes the isoenzymes during the course of hepa-

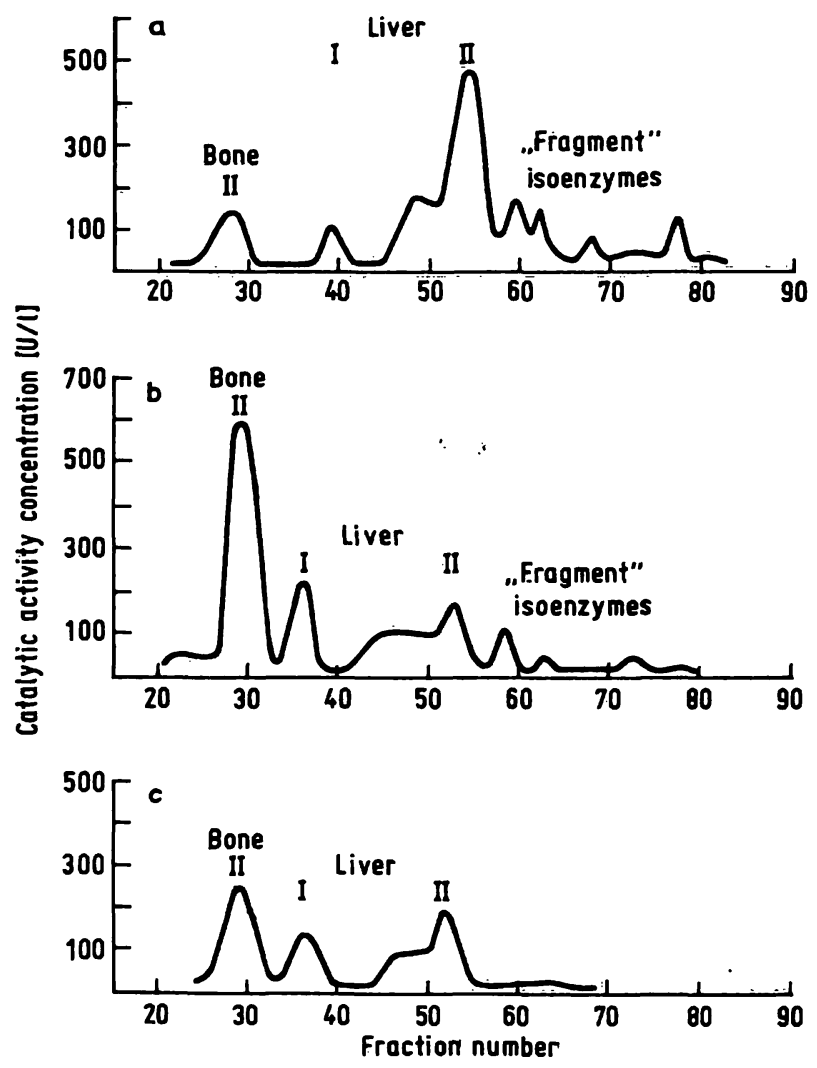

Fig. 6. Serum isoenzyme pattern in a case development of combined liver and bone disease ( $\delta, 9$ weeks).

\begin{tabular}{|c|c|c|}
\hline Sample & $\begin{array}{l}\text { Totàl } \\
\text { activity } \\
\text { (U/A) }\end{array}$ & 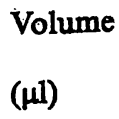 \\
\hline \multirow{3}{*}{$\begin{array}{l}\text { a) serum, during hepatitis } \\
\text { b) serum, } 6 \text { weeks later: } \\
\text { hepatitis and rickets } \\
\text { c) serum, } 2 \text { weeks after therapy } \\
\text { with vitamin D }\end{array}$} & 1600 & 100 \\
\hline & 2427 & 100 \\
\hline & 1800 & 100 \\
\hline
\end{tabular}


titis and additional rickets (separation 15). The changing pattern of the isoenzyme activities during therapy with vitamin $D$ is demonstrated in separation 16. This development shows, that the rise of the alkaline phosphatase acitivity was caused by an increase of bone isoenzyme and that therapy led to a reduction.

Our analysis of three patients with transient hyperphosphatasaemia (data not shown) shows that the activities of all described isoenzymes were elevated, but the biliary isoenzyme was not detectable.

\section{Discussion}

Measurement of the activity of alkaline phosphatase plays an important role in clinical-chemical diagnosis, but its usefulness is limited, because the total activity is composed of several individual isoenzyme activities. Particularly the interpretation of total alkaline phosphatase activity in paediatric patients is very difficult. The wide range of normal values in the individual age groups makes it difficult to define pathological activities of alkaline phosphatase. Determination of isoenzyme activities becomes essential, especially in cases of uncertainty. As demonstrated in figure 6 in combined liver and bone diseases, the total activity of alkaline phosphatase can only be conclusive when the activities of isoenzymes are known. By separating the isoenzymes, the cause of the increase of alkaline phosphatase activity can be determined. This example illustrates that the separation of alkaline phosphatase isoenzymes is a valuable method for diagnosis and therapy control in diseases of liver and bone. This method makes it possible to reduce the scale of additional diagnostics (measurement of other liver enzymes, calcium, phosphate, parathyrin and radiodiagnosis).

In accordance with our results, Johnson et al. identified two bone isoenzymes by electrophoresis in polyacrylamide (18). Their results confirm the overlap of the small intestine isoenzyme with the first bone isoenzyme. They called the first bone isoenzyme "Growith AP".

Walker et al. found two isoenzymes in liver, which they called "slow-" and "fast liver" (19). Crofton et al. used ion exchange chromatography to separate the biliary isoenzyme. They named it "High Molecular Weight Alkaline Phosphatase" (20). The isoenzymes which are characterized in the literature are comparable to the isoenzymes of our separation method, except for those we call "fragment isoenzymes". Hitherto no such alkaline phosphatase isoenzymes have been described. With reference to Klein et al., who reported that alkaline phosphatase isoenzymes are catabolized in the liver and partially secreted into the bile (21), we suggest that the fragment isoenzymes represent catabolites of different isoenzymes.

Heat inactivation studies show that the bone isoenzyme is the most heat sensitive. This corresponds to the results from Posen et al. (12), who demonstrated a similar pattern of heat sensitivity. According to Caspary the bone isoenzyme is particularly important for the diagnosis of pathological processes of the bone, because normally bone alterations can only be detected by radiodiagnosis if the calcium deficiency amounts to $30-50 \%$ (22). Our examples of phosphate diabetes and rickets show pathological activities for the bone isoenzymes. This is caused by augmented release of calcium and phosphate from bone.

The behaviour of the first and second liver isoenzymes is of special interest. Highest activities of the second liver isoenzyme were found in cases of hepatitis. On the other-hand, elevations of the first liver isoenzyme and the biliary isoenzyme were characteristical of cholestasis. There is evidence in the literature that the first liver isoenzyme is part of the liver cell membrane and is removed by bile acids which accumulate during cholestasis. Schlaeger et al. demonstrated that the alkaline phosphatase as well as other membrane-bound enzymes are more soluble if the concentration of bile acids is increased (23). The second liver isoenzyme seems to be localized in the cytosol. Like other cytosolic enzymes it shows high serum activities during various forms of cell damage, such as hepatitis. Our supposition corresponds to the results of Simon et al., who showed that alkaline phosphatase is localized at the membrane as well as in the cytosol of the rat liver cell (24). In addition they demonstrated that the membrane-bound alkaline phosphatase activity is increased in bile duct obstruction, while the cytosolic alkaline phosphatase remained unaltered. The importance of the biliary isoenzyme for the diagnosis of cholestasis is known. In 111 out of 123 cases of cholestasis, Siede et al. demonstrated that the serum biliary isoenzyme is a highly specific and sensitive indicator for cholestasis (25). Its specifity as an indicator for cholestasis was even higher than that of LP X. De Broe characterized the biliary isoenzyme as a vesicle originating from fragments of the liver cell membrane during cholestasis (26). Our own results showed it to be present in two cases of congenital occlusion of the bile duct. However both represented advanced cases with already existing biliary cirrhosis. It will be of interest to find whether this method is able to discriminate between congenital atresia of the bile duct and hepatitis of the newborn. 
The advantage of our method for separating the isoenzymes of alkaline phosphatase is its precision. This method improves the diagnostic value of the alkaline phosphatase determination. Moreover it allows the clarification of problems of differential diagnosis in liver and bone diseases.

\section{References}

1. Crofton, P. M. (1982) CRC Crit. Rev. Clin. Lab. Sci. 16, $161-94$.

2. Thomas, L. (1984) Labor und Diagnose. Die Medizinische Verlagsgesellschaft Marburg/Lahn, pp. 37-45.

3. Moss, D. W. (1982) Clin. Chem. 28, 2007-16.

4. Mc Kenna, M. J., Hamilton, T. A. \& Sussman, H. H. (1979) Biochem. J. 181, 67-73.

5. Stinson, R. A. \& Seargeant, L. E. (1981) Clin. Chim. Acta $110,261-272$.

6. Crofton, P. M. \& Smith, A. F. (1979) Clin. Chim. Acta 98, 253-261.

7. Bahr, M. \& Wilkinson, H. J. (1967) Clin. Chim. Acta 17, 367-370:

8. Fishman, W. H., Green, S. \& Inglis, N. I. (1963) Nature 198, 685-686.

9. Lin, C.-W., Sie, H.-G. \& Fishman, W. H. (1971) Biochem. J. $124,509-516$.

10. Lin, C.-W. \& Fishman, W. H. (1972) J. Biol. Chem. 247, $3082-87$.

11. van Belle, H. (1976) Clin. Chem. 22, 972-976.

12. Posen, S., Neale, F. C. \& Clubb, J. S. (1965) Ann. Intern. Med. 62, 1234-43.

13. Fritsche, H. A. \& Adam Park, H. R. (1972) Clin. Chem. $18,417-421$.

\section{Acknowledgement}

We thank the laboratory staff for their friendly help and cooperation.

11

14. Laan, H. W., Diaz, D. \& Szakaley, M. (1979) Clin. Chim. Acta $91,147-152$.

15. Siede, W. H. \& Seiffert, B. (1977) Clin. Chem. 23, 28-34.

16. Stigbrand, T. (1984) Human Alkaline Phosphatase. Alan R. Liss, Inc., 150 Fifth Avenue, New York, NY 10011. pp. $3 ! 14$.

17. Van de Voorde, A., de Waele, P., de Groote, G., Pollet, D., de Broe, M. \& Fiers, W. (1984) Human Alkaline Phosphatase. Alan R. Liss, Inc., 150 Fifth Avenue, New York, NY 10011. pp. $299-307$.

18. Johnson, R. B., Ellingboe, K. \& Gibbs, P. (1972) Clin. Chem. 18, 110-115.

19. Walker, A. W. \& Polard, A. C. (1971) Clin. Chim. Acta 34, 19-29.

20. Crofton, P. M. \& Smith, A. F. (1979) Clin. Chim. Acta 98, 253-261.

21. Klein, U. E. (1969) Dtsch. Med. Wochenschr. 94, 526-529.

22. Caspary, W. F. (1977) Intern. Praxis 17, 149-152.

23. Schlaeger, R., Haux, P. \& Kattermann, R. (1982) Enzyme $28,3-13$

24. Simon, F. R. \& Lutherland, E. (1977) Enzyme 22, 80-90.

25. Siede, W. H. \& Seiffert, U. (1983) Clin. Chem. 29, $698-700$.

26. De Broe, M. E., Borges, M. \& Wiene, R. J. (1979) Clin. Chim. Acta 59, 369-372.

Eckhard Schönau

Kinderklinik und Poliklinik

der Universität Êrlangen-Nürnberg

Loschgestraße 15

D-8520 Erlangen 